\title{
Anthrax Seroprevalence in Central Java, Indonesia
}

\author{
Dhani Redhono'), Paramasari Dirgahayu²) \\ 1)Sub Division Tropical Medicine and Infectious Disease, Internal Medicine, \\ Faculty of Medicine, Sebelas Maret University, Dr. Moewardi Hospital \\ 2)Biomedic Laboratory, Faculty of Medicine, Sebelas Maret University Surakarta, Indonesia
}

\begin{abstract}
Background: Anthrax is a zoonotic disease that is caused by Bacillus Anthracis is transmitted to humans through infected animal. The transmission to humans occurs when there is a contact to animals or animal products contracting anthrax. Clinical skin manifestations and anthrax serum Ig $\mathrm{G}$ antibody can be used to diagnose infected anthrax animals. This study aimed to determine the prevalence of anthrax based on ELISA serum Ig $G$ antibody and clinical skin manifestations occurring in patients with anthrax.

Subjects and Method: This was a descriptive study with cross sectional design conducted in Sragen district, Central, Indonesia, in 2015. A sample of 101 patients infected with anthrax was examined based on clinical skin manifestations and anthrax serum Ig G antibody.

Results: $39.6 \%$ of the sample was 21 to 40 years of age. $57.4 \%$ of the sample was female. $74 \%$ of the sample completed primary school. 21\% worked as farmers. 30.5\% of the sample who cooked and consumed meat showed positive Ig G. Test results showed serum Ig G antibody negative 50\%, $15.8 \%$ and $33.7 \%$ borderline positive. Clinical manifestations in the skin as much as $11.9 \%$, which is the eschar on all respondents and $92.8 \%$ showed positive Ig G. While $88.1 \%$ did not show any clinical signs of anthrax.

Conclusion: The increase in serum antibody titer Ig $G$ anthrax is not all respondents were exposed, in an area that otherwise outbreak of anthrax, which is only a third of all respondents, and when it comes up eschar will be followed by an increase in Ig G antibody titer.
\end{abstract}

Keywords: cutaneous anthrax, Ig G antibody ELISA, eschar

Correspondence:

Dhani Redhon. Sub Division Tropical Medicine and Infectious Disease, Internal Medicine.

\section{BACKGROUND}

Anthrax is a zoonotic disease that can be transmitted to humans from animals affected of anthrax. A bacillus anthracis bacterium often affects animals such as cows, sheep, goats, and camels. Transmission to human occurs when there is contact of animals suffered anthrax directly. It can be a skin, blood, and flesh. In addition, transmission can also occur when a person inhales the spores of diseased animal product, example skin or fur dried (Thunder, 2011)

The prevalence of anthrax in the world, in United States, there were 400 cases of anthrax during 1845-1955. Eighty percent of patients contact with wool, goat hair, or their imported products from Asia, Africa, and the Middle Eastern. In 1945, the extraordinary events have occurred in one million sheep die, so that vaccination program to be done in masse. It made mortality in pets dropped. Anthrax spores remains in the soil some parts of the world. It was also reported six cases of anthrax in 1978 that struck the agriculture and textile factory employees than England in period 1965 to 1980 . That found 145 cases, which were 23 no related to work, 19 male and 15 as workers fodder (Dixon 2005). 
Indonesian Journal of Medicine (2016), 1(2): 129-135

https://doi.org/10.26911/theijmed.2016.01.02.07

Currently the anthrax incident in Indonesia occurred in eleven provinces spread across islands in the country, namely in Koala, South Sulawesi in 1832, there were 36 patients died after eating meat in 1969. Four years later four patients died after eating meat infected of anthrax in Betung Gulf, Lampung in 1884, Buleleng, Bali and Palembang, East Sumatera in 1885. Bima, NTB in 1976 and Paniai, Irian Jaya in 1985 thousands of dead pigs and 11 patients died from eating pork. A total of 48 cases happened in Semarang, Boyolali, and Demak (Central Java) in 1990 with no death. The last occurrence in 1992, when anthrax attack Kopen, Teras, Boyolali, Central Java on the incident recorded 25 patients tested positive for anthrax and 18 of them dead.

The period of the last ten years has occurs five times the plague that in 1996 of Purwakarta, Subang, Bekasi, and Karawang, in 1997 of Purwakarta, Subang and Karawang. In 1999 in Purwakarta, Subng and Bekasi and in 2000 anthrax attack West Java with 32 cases in 2001 in Bogor with 22 patients infected with the death of two patients. This happened when Eid Adha of Coventry Cibinong and Babakan Madang which resulted in two patients died.

On February 2011, in Boyolali obtain a single cow that died of anthrax. The case was attacked nine patients, without death. It because patients do not know when the cow slaughtered and consumed in the vicinity was sick cow. On May 2011 outbreak in Sragen, Central Java with patients as 13 cases with no death (Mardianto 2011).

\section{SUBJECTS AND METHOD}

This was an analytic observational study with cross sectional design. It performed immunoassay based on patients exposed to anthrax outbreak in 2011. The samples were extraordinary outbreak of anthrax areas in
Boyolali and Sragen, Central Java. This incident occurred in February and in November 2011 in Boyolali, and in May in Sragen. All persons exposed to animals that died from anthrax, a blood sample for examination Ig G antibody serum by Examination of Enzyme-Linked Immunosorbent Assay (ELISA).

ELISA aimed to determine the serum antibody titer Ig G anthrax exposed to anthrax analyzed using Calbiotech Anthrax Protective Antigen (PA) Ig G ELISA Kit in Biomedical Laboratory of Medical Faculty, Sebelas Maret University of Surakarta.

\section{Definitions}

Anthrax is a zoonotic disease that occurs in animals, especially herbivores that can be transmitted to humans, direct or indirectly (Thunder, 2011).

\section{Risk Factors}

The risk transmission will occur when there is direct with infected animals or the environment in his life (cage) or from the product of sick animals for example skin, hair that has been dried, it can even happen due to slaughtering, flaying, cooking then eating meat of animal infected with anthrax. (Redhono, 2011).

\section{Clinical manifestations}

Anthrax appears as cutaneous anthrax, respiratory (inhalation anthrax) and digestive (gastrointestinal anthrax). Ninety-five percent of cases in the world are cutaneous anthrax, which is mostly the case with a better prognosis than other types of inhalation and gastrointestinal. Cutaneous anthrax usually occurs due to their history of contact animal and their products, which is marked by the entry of bacteria or anthrax spores penetrate the skin through a lesion on the skin, such as when doing slaughtering process (cutting, skinning, or divide meat) with anthrax infected. There was a low level of germination at the location where the entry of the spores and cause 
lesions in the skin itchy, then raised papuler lesions and develop into vesicles accompanied by edema and pain. These lesions then become local necrosis with eschar formation and soft tissue edema. Germination occurs within 1-3 hours after inoculation, but this germination cannot cause infection of the skin intact. Endospores will undergo phagocytosis by macrophages and then be taken to the regional lymph nodes, causing lymphadenopathy and lymphangitis (Scott 2009).

Location is often the case is on the face, extremities or the neck. Endospores enter through skin abrasions or cuts. One to seven days after entry endospores, formed a primary skin lesion that is not painful and itchy papules. Twenty-four to 36 hours later lesions forming vesicles containing clear liquid or serosanguineus containing many gram-positive bacteria. Vesicle then undergoes central necrosis, dry out and cause eschar (necrotic ulcers) distinctive blackish purple with edema and vesicles. Edema usually occurs more severe on the body than the head or neck or leg. Lymphangitis and lymphadenopathy pain can be found following systemic symptoms occur. Although anthrax skin can heal itself, but still need to be given antibiotics (to reduce systemic symptoms occur). In 80-90\% of cases the lesions recover completely without complications or scarring (Scott 2009).

Gastrointestinal anthrax usually occurs 2-5 days after eating raw or undercooked meat that is contaminated with germs. On pathological examination using microscope can be found bacilli in the mucosa and sub-mucosa and lymphadenitis mesenteric lymph tissue. Ulcerations almost always found. A large number of gram-positive bacteria can be found in the peritoneal fluid. Clinical symptoms can include fever, diffuse abdominal pain, consti- pation or diarrhea. Ascites can occur with clear liquids until purulent (WHO 2010).

Inhalation anthrax spores began with the entry into the alveolar cavity, then macrophages will phagocytic spores and most of the spores will lysis and broken. Spores are still alive will spread to the lymph nodes and mediastina nodes. The process of change in vegetative form occurs approximately 60 days later. The slow process of change in shape is not known with certainty, but well documented in Sverdlovsk that inhalation anthrax cases occurred between day 2 to day 43 after exposure. Once germination has occurred, the disease will arise quickly and replication of the bacteria causing hemorrhage, edema and necrosis (Pile 2005).

\section{Examination Support Anthrax}

Diagnosis of anthrax can be confirmed with confirmation of the results of routine blood tests, culture swab on the wound or blood (on the skin), phlegm (on inhalation) chest X-ray (on inhalation), electrolyte (GI) and serology using ELISA (Enzyme Linked Immunosorbent Assay) and PCR (Polymerasi Chain Reaction). Samples were taken for laboratory examination of the above is blood serum, rub the injured area, phlegm and land near the cage or a dead animal (Dirgahayu 2011).

ELISA procedure begins with the collection of samples for the ELISA test, namely:

1. The specimens used were obtained from blood serum suspected anthrax in the field. And serum is obtained by centrifugation.

2. For the purposes of transport of samples from a remote location so that the sample must be outside lab> 2 hours, samples should be brought in a thermos of ice/ refrigerated at 2-8 ${ }^{\circ} \mathrm{C}$, it can last for as long as seven days or frozen if it needs 
to be stored for an extended period time for six months.

3. Avoid repeated freezing and thawing process of the sample. To avoid this, the sample should be made directly aliquots and stored frozen.

Sampling and handling samples for the ELISA test, namely:

1. The specimens were obtained from blood samples were then centrifuged to obtain the sample.

2. Prior to the analysis, the specimen can be kept in a refrigerator at a temperature of $2-8^{\circ} \mathrm{C}$ for 6 months. Aliquot samples should be done to prevent damage to the protein.

3. Preparation of reagents required ie Washing Buffer. Prepared by adding washing buffer (25 ml of $20 x$ washing buffer is added to $475 \mathrm{ml}$ of distilled water. Store at room temperature.

All specimens and Reagent Kit is brought to the room with room temperature (18-26 $\left.{ }^{\circ} \mathrm{C}\right)$ and slowly do the mixing, by: (Dirgahayu 2011)

1. Place sticker and make labeling of all samples correctly

2. The negative control, positive control and calibrator prepared.

3. Prepare a 1:41 dilution of the sample solution by adding $200 \mu \mathrm{L}$ diluting the sample into the sample $5 \mu \mathrm{L}$. Mix gently.

4. Enter $100 \mu \mathrm{L}$ serum that has been diluteed, the solution calibrator and control solutions in wells ELISA plate. As a negative control used $100 \mu \mathrm{L}$ diluent buffer and put into wells at number $1 \mathrm{~A}$. Tap-tap the tray slowly to remove the air bubbles and mix gently with the micropipette with its tip replacing each sample change. Leave at room temperature for 30 minutes.

5. Discard the liquid in the tray wells and wash wells 3 times with $300 \mu \mathrm{L} 1 \mathrm{x}$ wash- ing buffer. Attach the surface of the tray to the paper towel so that the liquid can come out entirely.

6. Enter $100 \mu \mathrm{L}$ TMB substrate solution in wells ELISA tray. Let stand for 10 minutes at room temperature.

7. Add $100 \mu \mathrm{L}$ buffer stop solution to stop the reaction of the TMB working soluteion.

8. Later in the ELISA tray insert into the machine ELISA (micro well reader)to read the OD value of absorbance at 450 $\mathrm{nm}$

Interpretation of ELISA test results are:

$<0.9$ : Negative, is not detected IgG antibodies against the protein PA on ELISA.

o.9-1.1: Borderline positive. Recommended for reexamination.

> 1.1: Positive, is detected IgG anti-bodies against proteins PA, pa-tients indicated being infected or have been infected with a Bacillus Anthracis.

\section{RESULTS}

The basic characteristics of research subjects.

Table 1. Basic characteristics of research subjects

\begin{tabular}{lcc}
\hline \multicolumn{1}{c}{ Variables } & n & \% \\
\hline Gender & & \\
Male & 43 & 42.6 \\
Female & 58 & 57.4 \\
Age & & \\
O-20 years & 2 & 1.9 \\
21-40 years & 40 & 39.6 \\
41-60 years & 37 & 36.6 \\
61-80 years & 22 & 21.7 \\
Educations & & \\
Elementary School & 75 & 74.3 \\
Junior High School & 15 & 14.9 \\
Senior High School & 5 & 5.0 \\
Bachelor & 6 & 6.0 \\
Occupations & & \\
Doesn't work & 48 & 47.6 \\
Peasants & 22 & 21.8 \\
Civil Servants & 5 & 5.0 \\
Entrepreneur & 26 & 38.8 \\
\hline
\end{tabular}


In this study, 101 patients with a history of contact with animals infected with anthrax. The youngest age is 6 years (1\%) and the oldest 80 years (1\%). The distribution of age is the highest in the 21 to 40 years as much as $39.6 \%$, and most were female gender, i.e. 57.4\%. The education level of most respondents is $74.3 \%$ finished primary school, farmers as much as $\mathbf{2 1 . 8 \%}$.

The results obtained Ig $\mathrm{G}$ serum antibody showed a negative 50.5\%, $15.8 \%$ and $33.7 \%$ borderline positive. ELISA serology results are shown in Table 2.

Table 2. ELISA Inspection Results

\begin{tabular}{lcc}
\hline \multicolumn{1}{c}{ Variabels } & n & \% \\
\hline Positive & 34 & 33.7 \\
Borderline & 16 & 15.8 \\
Negative & 51 & 50.5 \\
\hline
\end{tabular}

In cross-table analysis results between the risk factors contact with ELISA serology results obtained respondents who cook and eat at the same time is the highest risk on the results of serological positive $20.8 \%$. Serology results Elisa Risks associated with the contact listed in Table 3 .

Table 3. Results Serology Elisa Risks associated with contact

\begin{tabular}{lccc}
\hline \multicolumn{1}{c}{ Contex } & \multicolumn{2}{c}{ Elisa Serology } & Negativ \\
\cline { 2 - 3 } & $\begin{array}{c}\text { Positiv } \\
\text { e }\end{array}$ & $\begin{array}{c}\text { Borderli } \\
\text { ne }\end{array}$ & e \\
\hline $\begin{array}{l}\text { Wash } \\
\text { meat }\end{array}$ & 1 & 0 & 1 \\
$\begin{array}{l}\text { Eat } \\
\text { Wash }\end{array}$ & 10 & 5 & 16 \\
$\begin{array}{l}\text { and Eat } \\
\text { Cook }\end{array}$ & 3 & 2 & 0 \\
$\begin{array}{l}\text { and Eat } \\
\text { Slaught } \\
\text { er and }\end{array}$ & 9 & 6 & 19 \\
$\begin{array}{l}\text { Eat } \\
\text { Be close } \\
\text { to cage }\end{array}$ & 0 & 0 & 13 \\
\hline
\end{tabular}

Overall there are $11.9 \%$ of respondents who showed clinical signs of the emergence in the skin in the form of vesicles, accompanied by fever and ulcers that ended with the formation of eschar. The skin manifestations can be seen in Table 4 .

Table 4. Skin Manifestations in The Form of Eschar

\begin{tabular}{ccc}
\hline Skin Manifestations & $\mathbf{n}$ & $\mathbf{\%}$ \\
\hline Eschar & 12 & 11.9 \\
No eschar & 89 & 88.1 \\
\hline
\end{tabular}

At respondents with positive serology results showed $10.9 \%$ of skin manifestation of the emergence of eschar, while only $1.0 \%$ with borderline serology that shows cutaneous manifestations.

Twenty two percent of respondents with positive ELISA results, but does not cause any manifestation in the skin of eschar or other clinical signs (fever, myalgia, cough, tightness, nausea and vomiting). Elisa serology associated with skin manifestations in the form of eschar can be seen in Table 5 .

Table 5. Results Serology Elisa Associated with Cutaneous Manifestations in The Form of Eschar

\begin{tabular}{lccc}
\hline \multirow{2}{*}{ Eschar } & \multicolumn{2}{c}{ Serology Elisa } & \multirow{2}{*}{ Negative } \\
\cline { 2 - 3 } & Positive & Borderline & \\
\hline Exist & $11(10.9 \%)$ & $1(1 \%)$ & $0(0 \%)$ \\
Doesn't & $23(22.8 \%)$ & $15(14.8 \%)$ & 51 \\
ExisT & & & $(50.5 \%)$ \\
\hline
\end{tabular}

Contact risk factors to the emergence of skin manifestations, especially on the respondents were slaughtered at once ate beef (6.0\%), followed by washing and eating meat, at $3.0 \%$, while only wash the meat by $1.0 \%$, Contact by simply eating meat only, obtained $2 \%$ which will appear the eschar. The relationship between con- 
Indonesian Journal of Medicine (2016), 1(2): 129-135

https://doi.org/10.26911/theijmed.2016.01.02.07

tacts with the manifestation of the emergence of eschar can be seen in Table 6 .

Table 6. Relationship between contacts with the manifestation of the emergence of eschar.

\begin{tabular}{lcc}
\hline \multicolumn{1}{c}{ Variables } & \multicolumn{2}{c}{ Eschar } \\
& & $\begin{array}{c}\text { Available } \\
\text { Availabe }\end{array}$ \\
\hline $\begin{array}{l}\text { Washing } \\
\text { meat }\end{array}$ & $\mathbf{1}(1 \%)$ & $1(1 \%)$ \\
Eating & $2(2 \%)$ & $29(28.7 \%)$ \\
$\begin{array}{l}\text { Washing and } \\
\text { Eating }\end{array}$ & $3(3 \%)$ & $2(2 \%)$ \\
$\begin{array}{l}\text { Cooking and } \\
\text { Eating }\end{array}$ & o (0\%) & $36(35.6 \%)$ \\
$\begin{array}{l}\text { Slaughtering } \\
\text { and Eating }\end{array}$ & $6(6 \%)$ & $19(18.9 \%)$ \\
$\begin{array}{l}\text { Be Close to } \\
\text { The Cage }\end{array}$ & o (0\%) & $2(2 \%)$ \\
\hline
\end{tabular}

\section{DISCUSSION}

In January 2011 obtained a cow belonging to one of the people who suddenly fall and accompanied by seizures. The owners decided to slaughter cattle meat and sold to citizens as much as 40 packs. Samples of meat and cow's blood is checked in Labkesda Central Java Province and tested positive for anthrax. Seven days later seven residents who complained there was little bumps and itching, accompanied by swellling and wet lesions in the area under the eyes, hands, legs or feet, then taken to a health center and declared suspected anthrax. Furthermore, the derah declared outbreaks of anthrax. Then in May 2011 in Sragen also occurred the same thing and some people who show symptoms of anthrax skin contact.

Clinical manifestations such as eschar present in $11.9 \%$ of the respondents and all bermanifetasi as Antrak skin (cutaneous anthrax). Respondents were drawn from these two locations, got 101 serological samples are then examined serum Ig G Antibody anthrax. Of these 50.5\% negative and $33.7 \%$ positive, while $15.8 \%$ borderline. Clinical manifesttations in the form of a skin disorder that begins their benjoalan or injury which later lead to edema and end with eschar present in $10.9 \%$ of the respondents were Ig $\mathrm{G}$ antibody positive and $1.0 \%$ of respondents with Ig $\mathrm{G}$ borderline results. This is due to the emergence of antibodies against the anthrax bacteria on respondents who had clinical manifestations in the skin, but that cannot be explained is the result of antibodies obtained also borderline clinical manifesttations (see Picture 1).

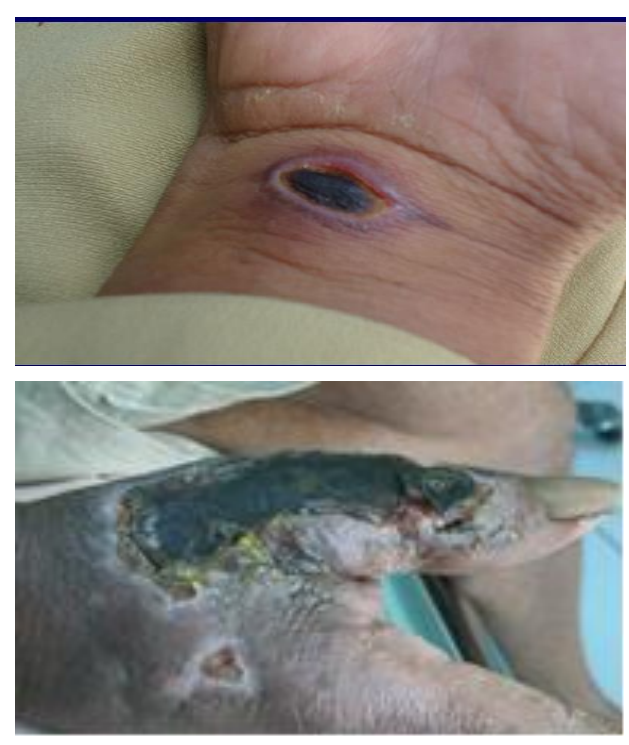

Picture 1. Anthrax manifestations in the skin with eschar appearance.

Twenty-two percent of respondents with positive serum Ig $\mathrm{G}$ antibody did not give rise to clinical manifestations. This might be due to the immune responder, bacterial virulence factors and the amount of exposure that occurs may not be too much. However this cannot be explained further, because of the durability factor of the bodies of all the conditions are similar, which is probably due to the virulence of germs and bacteria that enter the number. 
Therisk of direct contact, namely cooking and eating the flesh of infected animals showed 30.5\% IgG positive results, but did not cause clinical manifestations with the advent of eschar (o\%). This may be due to immune factors from the patient and the virulence of $B$ antrhacis that enter the body. Risk factors for eating just $32 \%$ of respondents showed positive results. While the risk factors slaughter and eat $24 \%$ of the skin manifests with the appearance of the eschar. The increase in serum antibody titer Ig G anthrax is not all respondents were exposed, in an area that otherwise outbreak of anthrax, which is only a third of all respondents, and when it comes up eschar will be followed by an increase in Ig G antibody titer.

\section{REFERENCE}

Braunwald E, Isselbacher KJ, Wilson JD, Martin JB, Kasper DL. Eds. Harrison's Principles of Internal Medicine. 16th ed. McGraw-Hill; New York: 892-899.

Centers for Disease Control and Prevention (2011). Guidelines anthrax. www.CDC.

Cieslak TJ, Eitzen E (2005). Clinical and epidemiologic principles of anthrax. Emerging infectious diseases (5): 552555.

Dirgahayu P (2011). Laboratory tests immunoassay based anthrax detection. Herman G. Anthrax: 18- 26.

Dixon TC, Meselson BSM, Guillemin J, Hanna PC (2005). Anthrax. N Engl J Med 341: 815-826.

Stern EJ, Uhde KB, Shadomy SV, Messonnier N (2008) CDC Case Definition. Public Health and Clinical Guidelines for Anthrax Affiliation 14.

Friedlander AM (2008). Anthrax. In: Medical aspects of chemical and biologic-
alwarfare.www.nbcmed.org/Site Content/HomePage/WhatsNew/MedAsp ects/Ch-22/electrv699.pdf.

Geoffrey Scott (2009). Anthrax. In: Mansons's Tropical Diseases 21st ed. Elsevier: China: 1109 - 1111.

Holmes RK (2009). Diphtheria, other corynebacterial infection and anthrax. In: Fauci AS.

Inglesby TV, Henderson DA, Bartlett JG (2005). Anthrax as a biological weapon of medical and public health management. JAMA 281: 1735-1745.

Inglesby TV, O'Toole T, Henderson DA, Bartlett JG, Ascher MS, Eitzen (2002). Anthrax as a biological weapon: Recommendations for management updated. JAMA 287 (17): 22362252.

Mardiatmo (2011). Anthrax disease prevention policies. Herman G. Anthrax: 3236.

Pile JC, JD Malone, Eitzen EM, Friedlander AM (2005). Anthrax as a potential biological warfare agent. Arch Intern Med 158: 429-34.

Redhono D, Sumandjar T, Hermawan G (2011). Mapping anthrax in Central Java. Herman G. Anthrax: 11- 17.

Shafazand S, Doyle R, Ruoss S, Weinacker A, Raffin TA (2005). Inhalation anthrax, Epidemiology, diagnosis and management. Chest 116: 1369-1376.

Sutarti E (2011). Anticipation of anthrax in animals. Herman G. Anthrax: 40-46.

Swartz MN (2001). Recognition and management of anthrax-an update. NEJM 345: 1621-1626.

WHO (2010). Guidelines for the surveylance and control of anthrax in humans and animals.www/who.int/emc document/zoonoses/docs/ whoczd.html. 